\section{Henry Stewart}

is Founder and Chief Executive of

Happy, a training company based in London. The company has been rated the best in the UK for customer service, by Management Today, and been listed in the top 20 workplaces in the UK for the last 4 years (Financial Times) Great Place to Work Institute).

Keywords: employee engagement, staff satisfaction, customer service

\section{When staff are not treated well}

\author{
Henry Stewart \\ Happy Ltd \\ Cityside House, 40 Adler Street \\ London, E1 1EE, UK \\ Tel: +44 2073757300 \\ Fax: +44 2073757301 \\ E-mail: henry@happy.co.uk
}

\section{Papers}

\section{Do happy staff make for happy customers and profitable companies?}

\author{
Henry Stewart
}

Received: 6th January 2010

\begin{abstract}
In today's business environment many companies are seeking to create great places to work in, partly prompted by the various Best Workplaces lists and partly in the belief that it will lead to greater commercial success. In this article Henry Stewart explores what evidence there is for the belief that a great workplace and more engaged staff have real bottom-line benefits.

Journal of Direct, Data and Digital Marketing Practice (2010) 11, 275-280. doi:10.1057/dddmp.2010.9
\end{abstract}

We all know that however strong the branding and however good the advertisements, it can all be wasted if the core customer experience is not up to scratch. Indeed, the most effective marketing takes place when it is closely aligned with that experience.

For my personal banking I have accounts with two banks (one for our joint account and one for my personal one). Whenever I contact First Direct I am left with a warm glow, feeling cared for by somebody who is helpful and efficient. The recommendations I regularly give to friends back up the advertisements they see. The same is not true of NatWest, who often infuriate me with their service, or lack of it. Their advertisements paint such a different picture to my experience that, when I see them, their only effect is to make me wonder why I haven't moved my account yet.

So what is it that creates different brand experiences like this? Is it clear rules and processes that are rigidly applied to always deliver the same service? Is it staff able to respond flexibly to your needs? Or is it the enthusiasm of staff that enjoy their jobs and show that in the welcome they give to customers?

We know what can happen when staff are not treated well. We have seen the examples of the Post Office and of British Airways. In the latter case, with strike negotiations continuing as I write, the fact that the staff apparently have far better pay and terms than their competition only makes one wonder what management must have done to so alienate their people: clearly, paying high salaries, relative to the competition, is no sufficient guarantee of a happy staff.

Contrast this with the enthusiasm about the product that you receive in an Apple store. Or the friendliness you get from (fairly low-paid) 


\section{Happy Staff = Happy Customers = Happy Profits?}

\section{Nandos' research on the secret behind its most successful branches}

\section{Asda: The correlation between engagement and profitability}

staff at the Asda check-out. Or the warm and relaxed welcome you will experience on Chiltern Railways, in stark contrast to those (in my experience) at South West or at Virgin Rail.

Motivation and engagement of employees may not be traditionally at the core of the concerns of marketing people, but perhaps it should be. If that element is not right, then all your best laid plans and spending could go to waste.

One of my favourite sound-bites is 'Happy Staff=Happy Customers = Happy Profits', which I first heard from the Northern Irish company Knock Travel. It would appeal to me, having set up a company called Happy Ltd. It is a link that seems to make sense. And, as companies compete to be in the various lists of the best places to work, it is a link that many assume to be true. But is there any evidence for this crucial connection between staff satisfaction and commercial success?

In setting up my company, which provides training in IT and in creating great workplaces, I was greatly influenced by a book published in the 1980s. Titled 'The Customer Comes Second', it was written by Hal Rosenbluth and Diane McFerrin, and I strongly recommend it. Its message on how to achieve business success can be summed up in seven words: 'Hire nice people and treat them well'. Or, to use the book's subtitle, 'Put your people first and watch 'em kick butt'.

What was particularly impressive about the message of the book was the track record of the authors. By putting its people first, Rosenbluth International - a billion-dollar travel management business - had in the mid-1980s won the Baldridge award for the best customer service in the entire US.

But this is, of course, not hard evidence. In terms of internal research, the restaurant company Nandos ${ }^{1}$ did some interesting work some years ago. They wanted to find out why some of their branches grew quicker than others. So they undertook a large piece of quantitative research, comparing a range of factors across dozens of restaurants. Their conclusion was clear: the strongest correlation with growth and profits was how happy staff said they were in the annual staff survey.

Interestingly, Nandos' response was to change their bonus system. Fully 50 per cent of managers' bonuses became based on the level of satisfaction staff showed in that survey. Nandos, of course, still wanted growth and profits, but they realized that bonusing their managers solely on those outcomes generated the wrong behaviours.

Further evidence comes from Asda, the 118 bn supermarket that employs 170,000 people. Back in 1990 the company was in severe difficulties, said to be just 10 days from bankruptcy. The turnaround has been based on a focus on engaging the front-line staff. Their measure of engagement has risen from 55 per cent in 1990 to 91 per cent today, and Asda was rated the best company to work for in the UK in the Sunday Times survey. 'Work made fun gets done' is one of the internal slogans.

'We have 360 separate P-and-Ls and I have done the calculations', explains David Smith, ${ }^{2}$ Head of People at Asda from 1990 to 2007. 


\section{Macleod report to government}

\section{Gallup: The effect of engaged employees}

\section{Does engagement lead to performance or vice versa?}

'There is an absolute positive correlation between staff engagement and profitability. If a branch can achieve an engagement level of 94 per cent I guarantee the profits will grow exponentially'.

Research into the companies that appear in the Sunday Times best workplaces list further indicates a correlation between a great work environment and commercial success. An investment in April 2001 of $£ 100$ in the 23 publicly quoted companies in the 2006 UK rankings would have been worth $£ 166$ by 2006, compared with $£ 132$ invested in the FTSE All Share Cumulative or $£ 125$ invested in the FTSE 100 (Financial Times, 18 May 2006).

The 2009 Macleod report to government, 'Engaging for Success', found a wide range of evidence indicating a direct link between employee engagement and business results. They defined an engaged employee as one who 'experiences a blend of job satisfaction, organizational commitment, job involvement and feelings of empowerment'.

In 2006, research by Gallup identified 12 core elements of employee engagement that they believe predict performance. These range from knowing what is expected of you to having the opportunity to do what you do best, every day, having a supervisor who seems to care about you and feeling that your opinions count.

The Gallup study, of 23,910 business units, compared the results from those in the top 25 per cent of engagement with those in the bottom 25 per cent.

- Those with engagement scores in the bottom quartile averaged 31-51 per cent higher employee turnover, 51 per cent more inventory shrinkage and 62 per cent more accidents.

- Those with engagement scores in the top quartile averaged 12 per cent higher customer advocacy, 18 per cent higher productivity and 12 per cent higher profitability. ${ }^{3}$

The same study looked at the earnings per share growth of 89 organizations: those with engagement scores in the top 25 per cent enjoyed growth 2.6 times that of organizations with below-average engagement scores.

MacLeod also quotes a global survey from HR consultancy Towers Perrin $^{4}$ in 2006, based on surveys of over 600,000 staff in a wide range of industries. 'Companies with high levels of employee engagement improved 19.2 per cent in operating income while companies with low levels of employee engagement declined 32.7 per cent over the study period'.

One of the strongest correlations was in the area of innovation.

'Fifty-nine per cent of engaged employees say that their job brings out their most creative ideas against only three per cent of disengaged employees'.

Of course it could be the case that a strongly performing company leads to strong engagement, rather than vice versa. Marcus Buckingham, previously of Gallup and now behind the Strengthfinder 


\section{The benefits of engaged staff}

\section{What should your management be focused on?}

Treat others as ... approach, concludes from various longitudinal studies that 'it is engagement that leads to performance, and this is a four times stronger relationship than performance leading to engagement'.

The example of Asda is interesting here. As David Smith ${ }^{2}$ explains, the turnaround was the result of the conscious decision to make staff engagement a key focus for the company. There was a big investment in recruiting the right people, managers with a more traditional command-and-control approach were moved out and making work fun became a priority. The results speak for themselves.

There is a range of clear benefits from engaged staff:

- Seventy per cent of engaged employees indicate that they have a good understanding of how to meet customer needs; only 17 per cent of non-engaged employees say the same. ${ }^{6}$

- Engaged employees are 87 per cent less likely to leave the organization than the disengaged. ${ }^{7}$

- Seventy-eight per cent of engaged employees would recommend their company's products or services, against 13 per cent of the disengaged. ${ }^{8}$

Let me put to you a simple belief: 'People work best when they feel good about themselves'. Stop for a moment and consider whether you agree with that statement. If you do, and most people I ask do agree, then there is a natural follow-up question: What should your management be focused on?

If that statement is true and the point of management is to get the most from people and enable them to work at their best, then the key role of management is surely to make people feel good about themselves. Think about it. How would management be different in your organization if their key role was seen as creating an environment where people feel good, where they feel valued and motivated?

What this involves will vary from employee to employee. The great managers are those that recognize this and understand that the age-old principle 'treat others as you would like to be treated' is insufficient. 'Treat others as they would like to be treated' is what is needed in the workplace.

I may like to be praised in public for great performance, and given a weekend away at an activity centre as a reward. For one of my people both would be hell. They would far prefer private praise and an afternoon off to go shopping as the reward.

But there are some common needs. If you ask people at my company why they like working there (and we have been listed in the Financial Times top 20 workplaces for the last 4 years), they will stress two things. First is a flexible work-life balance that enables them to choose how they work and judges them on what they produce not how long they are at their desks. Second is that they are trusted and given freedom to do their job in the way they feel is best. 


\section{The most common staff complaint}

\section{Only 21 per cent are actively engaged}

\section{Employee engagement is falling}

\section{Conclusion: The simplest route to a competitive advantage?}

In contrast, in the staff surveys we carry out for clients, "micro management' is the most common complaint. People resent being told what to do and having to go through layers of approval to implement anything new. They don't ask for complete freedom. Instead they generally make a very reasonable request: 'Make clear the guidelines and what you want me to achieve. And then give me the freedom to work out how to achieve that'.

Gary Hamel ${ }^{9}$ of London Business School quotes more recent research from Towers Perrin - this time a global survey of 90,000 employees from a variety of companies - which found that only 21 per cent of employees are actively engaged in their work. 'The other 79 per cent may be physically on the job, but they've left their enthusiasm and ingenuity at home', comments Hamel. While companies search for ways to reduce costs and increase productivity, just think of the untapped potential in that 79 per cent, a potential that could be released if those staff could be actively engaged.

Indeed, despite all the evidence of its benefits, there is evidence that levels of employee engagement are declining. Between 1992 and 2001 the proportion of people saying they had a great deal of discretion over how to do their work fell from 57 to 43 per cent. ${ }^{5}$

On the one hand, this is a tragic trend, especially as the economy is moving from a more industrial model, where lack of freedom over your job was common, to a service model. On the other hand, it provides a great opportunity to entrepreneurs and to forward-thinking organizations.

The research has been done and the evidence, quoted above in this article, is in. It is clear that a disengaged staff leads to poor company performance. In contrast, engaged and happy staff lead to great customer experiences and commercial success.

Companies like Asda have transformed their businesses by focusing on staff morale and satisfaction. Both Microsoft and Google made strategic decisions to target employee satisfaction with the aim of being the best place to work in Europe. (They were No. 1 and 2 in the Financial Times Best Workplaces survey in 2008.) For neither company was it out of some philanthropic desire. For both it was for solid business reasons: to enable recruitment of the most talented staff, and increase innovation and customer satisfaction.

However, the figures on declines in freedom in jobs indicate that this is still not the norm. The evidence seems clear that a more engaged and satisfied workforce produces significant gains in innovation, growth and profitability. It is simply one of the most effective ways to create a competitive advantage in the marketplace.

\section{References}

1. Nandos. (2006), From a speech by Marcelo Borges at Learning and Skills Council London Alumni 2006.

2. Smith, D. (2009), Asda: Speech at LBS Management Lab, 2 October 2009. 
3. Gallup. (2006) 'Engagement predicts earnings per share', Gallup 2006 (quoted in Macleod Review).

4. Towers Perrin. (2006) 'ISR employment engagement report', Towers Perrin-ISR (quoted in Macleod Review).

5. Office of Public Sector Information. (2009) 'Engaging for success: Enhancing performance through employee engagement' [MacLeod Review] Report to Government by David MacLeod and Nita Clarke.

6. CIPD. (2006) 'Measuring true employee engagement', Right Management 2006, CIPD.

7. Corporate Leadership Council. (2004) 'Driving performance and retention through employee engagement: A quantitative analysis of effective engagement strategies', Corporate Leadership Council 2004 (quoted in Macleod Review).

8. Flade, P. (2003) 'Great Britain's workforce lacks inspiration', Gallup Management Journal, December.

9. Hamel, G. (2009) 'The hidden costs of overbearing bosses', Labnotes, December 2009, London Business School MLab. 